\title{
Factors associated with retention in faith-based drug treatment centers in the Mexican-American border
}

\author{
letza Bojorquez, 'Daniel Rodríguez, ${ }^{2}$ Olga Odgers, ${ }^{3}$ Ramiro Jaimes ${ }^{4}$
}

1 Departamento de Estudios de Población, El Colegio de la Frontera Norte, Tijuana, México.

2 El Colegio de la Frontera Norte, Tijuana, México.

3 Departamento de Estudios Sociales, El Colegio de la Frontera Norte, Tijuana, México.

${ }^{4}$ Instituto de Investigaciones Históricas, Universidad Autónoma de Baja California, Tijuana, México.

\section{Correspondence:}

letza Bojorquez

Departamento de Estudios de Población, El Colegio de la Frontera Norte.

Carretera Escénica Tijuana-Ensenada km. 18.5, San Antonio del Mar, C.P. 22560, Tijuana, Baja California, México.

Phone: +52 664631 - 6300

Email: ietzabojorquez@gmail.com

Received: 8 March 2018

Accepted: 17 July 2018

Citation:

Bojorquez, I., Rodríguez, D., Odgers, O., \& Jaimes, R. (2018). Factors associated with retention in faithbased drug treatment centers in the Mexican-American border. Salud Mental, 47(4), 169-177. doi: 10.17711/SM.0185-3325.2018.025

(c) (i) (8)

\begin{abstract}
Introduction. Faith-based centers are major providers of residential treatment for substance use problems in Mexico, but relatively few studies have been conducted in this context. Objective. To explore factors associated with treatment retention in two faith-based (with different religious orientation) residential treatment facilities for male drug users in Tijuana, Mexico. Method. We conducted an exploratory follow-up study of 328 clients admitted during 2014-2015 to either an Evangelical Pentecostal center or a faith-based center without a specific religious affiliation. The main outcome was retention, defined as remaining in treatment for at least three months. Results. Among participants, the retention rate was $38.7 \%$. Multivariate logistic regression models showed that age $(O R 1.04 ; 95 \% \mathrm{Cl}[1.01,1.06] ; p=.002)$ and having used heroin or opioids in the past 30 days (OR .50; $95 \% \mathrm{Cl}[.25,1.00] ; p=.049)$ were associated with retention. Having a personal religious affiliation was associated with retention in the Evangelical Pentecostal center, but not in the center without a specific religious affiliation. Discussion and conclusion. The retention rate was low, but within the previously reported range. The interaction of personal religious affiliation and the religious orientation of the center suggests that a match between a person's religious convictions and those of the center could be important for retention. More research is needed to clarify the utility of faith-based centers for religious and non-religious drug users.
\end{abstract}

Keywords: Drug users, residential treatment, faith-based treatment, Mexico.

\section{RESUMEN}

Introducción. Aunque los centros de rehabilitación religiosos proporcionan tratamiento a un gran número de usuarios de drogas en México, existen relativamente pocos estudios sobre estos centros. Objetivo. Explorar los factores asociados con la retención en el tratamiento en dos centros de rehabilitación para hombres usuarios de drogas con diferentes orientaciones religiosas en Tijuana, México. Método. Estudio longitudinal exploratorio de 328 usuarios admitidos durante 2014-2015 en un centro evangélico pentecostal y en un centro religioso sin denominación específica. El resultado principal fue la retención, definida como la permanencia en tratamiento por al menos tres meses. Resultados. La tasa de retención entre los participantes fue de $38.7 \%$. En el análisis con modelos de regresión logística multivariada la edad $(O R$ 1.04; $95 \% \mathrm{Cl}[1.01,1.06]$; $p=.002)$ y haber utilizado heroína u opioides en los últimos 30 días (OR .50;95\% Cl $[.25,1.00] ; p=.049)$ se asociaron con la retención. Tener una adscripción religiosa personal se asoció con retención en el centro evangélico pentecostal, pero no en el centro sin afiliación religiosa específica. Discusión y conclusión. La tasa de retención observada fue baja, aunque dentro del rango previamente reportado. La interacción entre adscripción religiosa personal y orientación religiosa del centro sugiere que la concordancia entre estos dos elementos podría facilitar la retención. Se requiere más investigación en este contexto para clarificar la utilidad de los centros de rehabilitación religiosos en el tratamiento de usuarios religiosos y no religiosos.

Palabras clave: Usuarios de drogas, tratamiento residencial, centros religiosos de tratamiento, México. 


\section{INTRODUCTION}

Residential treatment is an important component of the management of substance use disorders (American Psychiatric Association \& Work Group on Substance Use Disorders, 2010). In Mexico, governmental resources for mental health are scarce (Berenzon, Saavedra, Medina-Mora, Aparicio, \& Galván, 2013), and while some private centers offer state-of-the-art, professional residential care, cost puts this kind of treatment out of reach for many users. Peer-support non-governmental centers for the residential treatment of addictions are therefore an important resource for people with few economic resources (Garcia, 2015; Garcia, 2015; Lozano-Verduzco, Marín-Navarrete, Romero-Mendoza, \& Tena-Suck, 2015; Marín-Navarrete et al., 2013). These centers employ different treatment models, generally including a combination of 12-step group sessions and involvement in the everyday chores of the center (such as cleaning, cooking, etc.). Few of them have health or mental health professionals as part of their staff, and they are usually directed by former drug users. This type of residential centers, sometimes called anexos, have also been accused of mistreatment and recurring to physical and emotional violence (Marín-Navarrete et al., 2013). Despite the importance of non-governmental faith-based rehabilitation centers in providing care to a high proportion of the most vulnerable drug users, still only a few studies have addressed their therapeutic procedures and outcomes (Marín-Navarrete et al., 2013).

Baja California has one of the highest drug use rates in Mexico, with a life time prevalence of $13.5 \%$, as compared with $9.9 \%$ at the national level in 2016 (Instituto Nacional de Psiquatría Ramón de la Fuente Muñiz, Instituto Nacional de Salud Pública, Comisión Nacional Contra las Adicciones, \& Secretaría de Salud, 2017). While there is no complete record of non-governmental treatment centers in Baja California, in 2013 there were 233 of them registered with the Ministry of Health, many of which were operated by Evangelical Pentecostal (EP) groups (Galaviz \& Odgers, 2014).

Retention in treatment is associated with improved long-term results in areas as diverse as employment, social networks, criminality, substance use, and need of treatment re-entry (Evans, Li, \& Hser, 2009; Garnick, Lee, Horgan, Acevedo, \& Washington Circle Public Sector, 2009). Rates of retention in residential treatment vary worldwide, from as much as $88 \%$ for a 28 -day treatment (McKellar, Kelly, Harris, \& Moos, 2006) to around 50\% for three-month programs (Meier \& Best, 2006; Mulder, Frampton, Peka, Hampton, \& Marsters, 2009). While longer periods of treatment are associated with better outcomes, a minimum period of three months is recommended by the American Psychiatric Association for the residential treatment of patients with substance use disorders (American Psychiatric Association \& Work Group on Substance Use Disorders, 2010), and this period has also been associated with a significant improvement (as measured by change in frequency of substance use) on both primary and overall drug use among long-term residential treatment clients (Zhang, Friedmann, \& Gerstein, 2003).

Many factors associated with treatment retention have been reported in the literature. Among them are older age (Arndt, Acion, \& White, 2013; McKellar et al., 2006), higher educational attainment (Arndt et al., 2013), social support (Lang \& Belenko, 2000; Lewandowski \& Hill, 2009), and court-mandated admission (Arndt et al., 2013). Psychological traits such as better cognitive functioning (Aharonovich et al., 2006; McKellar et al., 2006), problem-oriented coping style and internal locus of control (Meier, Donmall, McElduff, Barrowclough, \& Heller, 2006; Tate et al., 2008) can also influence retention. The pattern of drug use is associated with retention as well, as users of alcohol, marihuana, or amphetamines tend to stay in treatment longer than those of cocaine or heroin, and poly-users are less likely to complete treatment (Arndt et al., 2013).

The outcome of faith-based residential treatment for drug use is a relatively under-researched subject. Only a few studies have addressed retention in this context (Parhami, Davtian, Collard, Lopez, \& Fong, 2014; Sung \& Chu, 2013), and they report retention rates similar to those of other types of centers. Besides the factors already cited, retention in faith-based centers could be associated with the client's spirituality at entry (Parhami et al., 2014), and also with religious conversion or the renovation of faith (Sung \& Chu, 2013).

The objective of this study was to assess retention, and factors associated with it, for two faith-based non-governmental residential treatment centers in Tijuana, Baja California, Mexico. Based on findings reported by the previous literature, our hypotheses were that higher odds of retention would be associated with: older age, higher educational attainment, court-mandated admission, internal locus of control, use of substances other than cocaine or heroin and single-substance use, and higher religiosity and spirituality. We also hypothesized that specific religious affiliation would interact with the center's religious orientation, so that when the orientation of client and center coincided, retention would be more likely.

\section{METHODS}

\section{Study design}

This was a cohort study of interns in two treatment centers.

\section{Sites}

The study was conducted in two centers, henceforth referred to as $\mathrm{C} 1$ and $\mathrm{C} 2$. $\mathrm{C} 1$ is an EP center, directed by a 
minister, and the religious practices and belief system of Evangelical Pentecostalism form the chore of its treatment model (Odgers, Galaviz, \& Hernandez, 2009; Stoll, 1990). C2 is 12-step based, and while spiritual aspects are considered central, it is not guided by a specific religion. Evangelical and Jehovah's Witnesses services are common but not mandatory, and Catholic altars and images are present in the facilities. Both centers accept male drug and alcohol users from 18 years of age. They have weekly visits by physicians, who are available for emergency calls, but no mental health professionals. Both centers provide free (or payable with work at the center) attention to clients in need, and charge a fee to those who can pay that varies depending on the length of treatment and the client's (or his family's) ability to pay. During the study, fees varied from roughly $\$ 1,000$ to $\$ 6,000$ Mexican Pesos $(\approx \$ 50-\$ 300$ US at the time of the study) for a three-month stay. This article is part of a wider study of the EP rehabilitation centers in Tijuana, and details of the story, characteristics, and treatment model of the centers can be consulted in previous articles (Galaviz \& Odgers, 2014; Hernández \& Ortiz, 2015). Recruitment for the study began in September 2014 and continued till June 2015.

\section{Participants}

All newly admitted clients (i.e., clients who were not already in the center at the time the study began) who fulfilled inclusion criteria and were willing to participate during the recruitment period. Inclusion criteria were: 1 . age 18 years or older; 2 . first admission at the center during the study period (i.e., no readmissions were included); 3 . having no cognitive, language or other impediments to understand the informed consent procedure and answer the questionnaires; 4 . agree to participation after an informed consent procedure.

\section{Measures}

We defined our outcome measure, retention, as having stayed in the center for at least 90 days. This was based on the one hand on the literature that suggests 90 days to be the minimum stay that provides significant benefits, and on the other because both centers defined their treatment as completed if the client had stayed for that period. We considered as retentions all clients who at the time of the 90day follow-up either: 1 . were still at the center; 2 . had left the center because of conclusion of their treatment period (self-reported or according to the center's records); 3. were at a different unit of the same center.

All independent variables were measured at baseline. Socio-demographic characteristics included age, education, marital status, and migratory experience in the United States. The last variable was included because in Tijuana some clients live in the United States and have come across the border for treatment, and some are return Mexican migrants (either voluntary or deported). Participants were also asked the motive of admission (response categories: voluntary, court-mandated, medical referral, school or workplace referral, and admitted at the request of family or friends).

We measured social support with the question "At the time of admission, were you in touch with your family?" (yes/no), and with the sum of four questions about perceived social support (e.g., "Do you usually have someone to show you love and affection?") with answers ranging from "never" to "always". Possible scores in the later ranged from $0-16$, with a higher score indicating more perceived support.

We assessed cognitive state with the Mini-Mental State Examination (MMSE), in the Spanish version employed by Mexico's Secretaría de Salud (Folstein, Folstein, $\&$ McHugh, 1975). Scores range from 0-30, with higher score indicating a better state. The MMSE has good sensitivity for the detection of cognitive impairment $(77 \%$ in a study with older adults, with a false-positive rate of $16 \%$ ) (Borson, Scanlan, Watanabe, Tu, \& Lessig, 2005). Having no standardized cutoff points for adult Mexican population, we employed the 25th percentile of a Mexican older adult population (Mokri, Ávila-Funes, Meillon, Gutierrez, \& Amieva, 2013), and excluded participants scoring 22 points or less.

Participants also completed the Brief Cope questionnaire in the Spanish version (Carver, 1997). The 24 items of the Brief Cope describe possible ways of responding to difficult or stressful situations, which are classified in 12 coping styles (Self-Distraction, Active Coping, Denial, Substance Use, Use of Emotional Support, Behavioral Disengagement, Venting, Positive Reframing, Planning, Humor, Acceptance, and Religion). The items corresponding to each style are summed to obtain style scores ranging from 2-8 (higher score indicates more frequent use of the coping style). The reliability of the 12 subscales included in the 24-item version of the Brief Cope ranges from Cronbach's $\alpha=.50$ to $\alpha=.82$ (Carver, 1997). Following the Brief Cope authors' recommendation, we employed for the analysis the score in each of the 12 styles as separate independent variables.

We evaluated locus of control with the Drug Related Locus of Control (DRLOC) questionnaire, a 15-item instrument that measures the perceived ability to control drug use, with a reliability coefficient Cronbach's $\alpha=.81$ and significant correlations with measures of addiction severity and self-esteem (Hall, 2001). The DRLOC consists of pairs of affirmations from which the participant must choose, one representing internal (scored as 1), and the other external locus of control (scored as 2). Following the authors recommendation, we averaged all 15 items for the analysis, for a resulting continuous score of $1-2$, with a value closer to 1 indicating internal locus of control, and a value closer to 2 indicating an external locus of control. 
To evaluate drug use in the previous month, participants were asked whether they had used each one of a list of substance types in the 30 days before admission to the center. We explored the association between each substance and retention, as well as the association between number of substances ( 1 vs. 2 or more) and retention. We also evaluated the association of retention with the number of previous residential and outpatient drug treatments.

To assess religiosity and spirituality, we employed the Duke University Religion Index (DUREL), a five-item inventory of participation in organized religious activities, participation in non-organized religious activities, and intrinsic religiosity (i.e., importance of spiritual aspects in the subject's life). The three dimensions are scored and analyzed separately, with higher scores indicating more religiosity/spirituality. The score for organized religious activities is the answer to the first question (response range 1-6); the score for non-organized religious activities is the answer to the second question (response range 1-6, reverse coded); and the score for intrinsic religiosity is the average of the three remaining questions (range 1-5). In diverse studies, Cronbach's $\alpha$ for DUREL ranges from .78-.91, and it has values of convergent validity with other measures of religiosity ranging from .71-.86 (Koenig \& Büssing, 2010). Lastly, we analyzed the response to a question about religious affiliation at the time of admission. The responses to this question were classified as no religious affiliation, Catholic, Non-Catholic Christian, and other.

\section{Procedures}

During the recruitment period, research assistants visited the centers weekly, recording the number of new admissions from the centers' registers and listing clients who had finished detox during the past seven days. Those who had finished detox in the previous seven days were invited to participate if they fulfilled the inclusion criteria. Those who agreed were screened with the MMSE (Folstein et al., 1975).

Follow-up interviews were conducted at 30,60, 90, 120 , and 180 days, from the date the participant had finished his detox period. A range of \pm 10 days around the programmed date was accepted for the interview. Follow-ups took place either at common areas of the centers (taking care that no third person was within hearing distance), or by phone when the participant had already left the center. Although the follow-up questionnaires included the baseline instruments, however in this article our dependent variable of interest is retention and the baseline characteristics associated with it. Therefore, we use information only from the baseline questionnaire and data on retention at the 90-day follow-up.

All field procedures were conducted by previously trained research assistants with at least some college educa- tion. The training included reviewing the aims of the project and the objective of each part of the questionnaire and practicing the application of questionnaires with members of the research group. A psychologist with a PhD in Neurosciences and experience in the application and research-related use of the MMSE provided training for the application of that instrument.

\section{Statistical analysis}

First, we conducted descriptive analyses of retention and of baseline characteristics of participants, overall and by center. To further explore the association between each independent variable and the dependent variable, we fitted bivariate models, stratified by center. As retention is a dichotomous outcome, with value of one if the participant had completed three months in treatment, and zero if he had not completed that period, we employed logistic regression to model the association.

Our main purpose in the statistical analysis was to assess the association between the independent variables and retention in treatment. We began with a model with all independent variables, and then sequentially eliminated variables with the higher $p$-values. We first obtained one model for each center, to observe if the independent variables associated with retention differed by center. Afterwards, we fitted a model for both centers, with the center as a further independent variable. We explored interaction terms of center-by-independent variable, for those independent variables that had shown differential effects between centers in the previous steps, and retained interactions with $p<.05$. We assessed the fit of the model for both centers with the same criteria as above. Missing data were handled with case-wise deletion. All analyses were conducted with Stata (Version 13) (StataCorp, 2013).

\section{Ethical considerations}

The Ethics Committee reviewed and approved all procedures in the study, and participants read and signed an informed consent form. The confidentiality of participants was guaranteed using an identification number in questionnaires (i.e., no name was registered in the questionnaires or data bases). Names and contact data of participants were kept in a password-protected file. Consent forms were kept in a locked drawer.

\section{RESULTS}

During the recruitment period, 610 clients were admitted to the centers, of which $486(79.7 \%)$ were invited to participate (Figure 1). Of those admitted, 6.7\% (41/610) abandoned treatment less than seven days after admission, so it 
was not possible to approach them during the weekly visits of the research team. A further 83 clients $(13.6 \%$ of those admitted) were not approached because the staff reported they were working or otherwise engaged at the time of the research team visit. According to the researchers' observations, some of them might have already left the center at the time, while others would be best described as polite refusals. The baseline questionnaire was responded by 328 participants (53.8\% of admissions). At the 90-days follow-up, 127 of them were still in or had completed treatment, for a retention rate of $38.7 \%$ (127/328). Assuming a scenario where all admissions for which there was no information had completed or were still in treatment at three months, the retention rate would have been $60.8 \%$ (371/610). Conversely, on a worst-case scenario, where all of them had abandoned treatment, the retention rate would have been $20.8 \%$ (127/610). The retention rate among those who completed the baseline interview was $32.5 \%$ (52/160) for $\mathrm{C} 1$, and $44.6 \%(75 / 168)$ for C2. Regretfully, the centers do not keep complete records on all admissions, so it is not possible to compare the characteristics of those who answered the baseline questionnaire, with those of all admitted.

In Table 1 we show the baseline characteristics of the 328 eligible participants. Mean age was 33.1 years, and the more frequently consumed drug was methamphetamine. Those who started treatment at C2 were slightly older, a

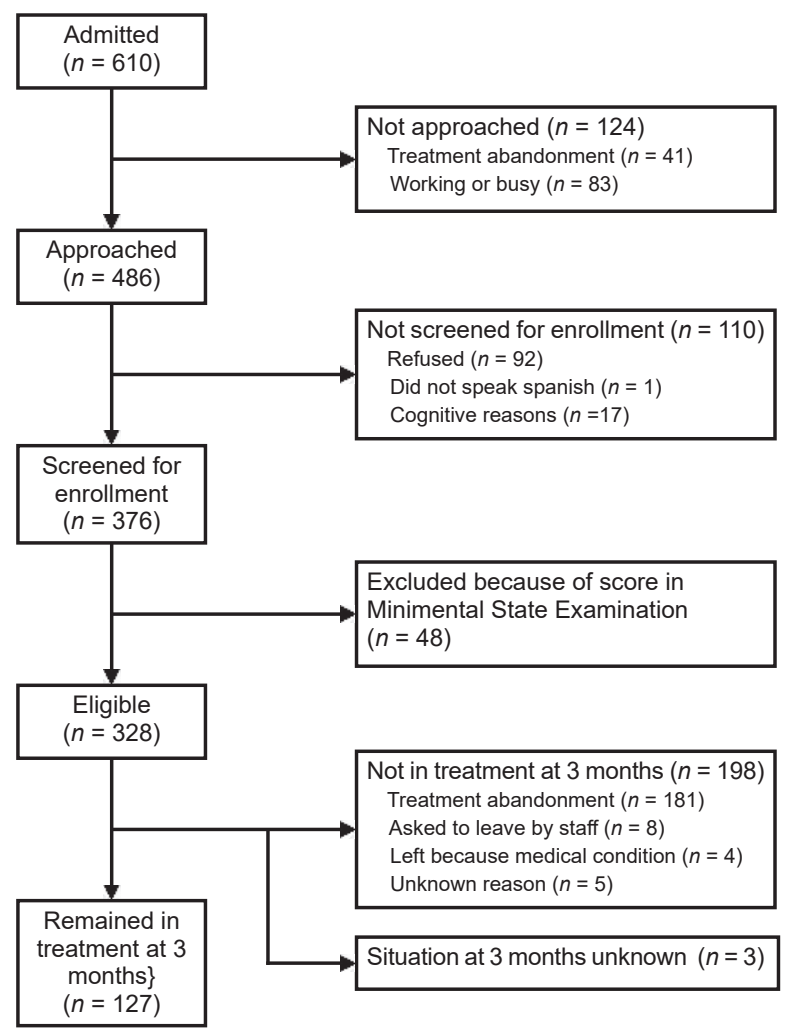

Figure 1. Flow diagram of admissions, enrolled in study and retained in treatment. higher percentage had lived in the United States, and the prevalence of heroine/opioid use in the last 30 days was also higher. The average score in the Intrinsic Religiosity subscale of the DUREL was higher in C1. A higher percentage of participants self-declared as Non-Catholic Christian in $\mathrm{C} 1$, while a lower percentage of participants had no religious affiliation. Scores in the Brief Cope subscales were similar between centers, except for a higher score in the Venting copying style (e.g., "I expressed my negative feelings") in C2 (not shown in Table 1). Of notice, none of the participants had been admitted by legal request (court-mandated admission): the only observed motives of admission were either voluntary or at the request of family or friends.

In Table 2 we show the associations of the independent variables with retention, stratified by center. In $\mathrm{C} 1$, older age was associated with higher odds of retention, while the Behavioral Disengagement copying style (e.g., "I gave up") was associated with lower odds. There was a significant bivariate association between retention and the religion copying style (e.g., "I prayed or meditated"), but it disappeared after adjusting for other variables. Methamphetamine use was associated with higher odds of retention. Catholic and Non-Catholic Christian religious affiliation were also associated with retention. In C2, having lived in the United States and having been admitted at the request of family or friends were associated with higher odds of retention, while using heroin/opioids was associated with lower odds.

In the final model combining data from both centers (Table 3), older age was associated with higher odds of retention, and using heroin/opioids with lower odds. As shown by the center-by-referral source interaction, having been admitted at the request of family or friends was associated with retention in $\mathrm{C} 2$, while no association was observed in $\mathrm{C} 1$. The center-by-religious affiliation interaction coefficient shows that in $\mathrm{C} 1$ being Catholic or Non-Catholic Christian was associated with retention, while in $\mathrm{C} 2$ religious affiliation had no observable effect. The interaction term can also be read as showing that those with no religious affiliation were more likely to stay in treatment in $\mathrm{C} 2$ than in $\mathrm{C}$, while for those with a religious affiliation the odds of staying were similar between centers.

\section{DISCUSSION AND CONCLUSION}

The $38.7 \%$ three-month retention rate in this study is low, but within previously reported ranges. Although differences in follow-up time make comparisons difficult, in the Christian residential treatment studied by Sung and Chu (2013), the 18-month retention was $18 \%$, and in the study by Parhami et al. (2014) of a Jewish religious treatment center the six-month rate was $55 \%$. In non-religious centers, retention rates also vary widely (McKellar et al., 2006; Meier \& Best, 2006; Mulder et al., 2009). 
Table 1

Baseline characteristics of participants, total and by center

\begin{tabular}{|c|c|c|c|c|}
\hline Variable & $\begin{array}{l}\text { Center } 1 \\
(n=160)\end{array}$ & $\begin{array}{l}\text { Center } 2 \\
(n=168)\end{array}$ & $\begin{array}{c}\text { Total } \\
(n=328)\end{array}$ & $p$-value ${ }^{1}$ \\
\hline Age (M, S.D. $)^{2}$ & $31.9(11.0)$ & $34.2(10.7)$ & $33.1(10.9)$ & .052 \\
\hline \multicolumn{5}{|l|}{ Education (\%) } \\
\hline $\begin{array}{l}\text { Elementary or less } \\
\text { Junior high } \\
\text { High school } \\
\text { College or more }\end{array}$ & $\begin{array}{r}24.5 \\
39.0 \\
33.3 \\
3.1\end{array}$ & $\begin{array}{r}25.6 \\
32.7 \\
36.9 \\
4.8\end{array}$ & $\begin{array}{r}25.1 \\
35.8 \\
35.2 \\
4.0\end{array}$ & .623 \\
\hline \multicolumn{5}{|l|}{ Marital status (\%) } \\
\hline $\begin{array}{l}\text { Single } \\
\text { Married/common law } \\
\text { Separated/divorced/widowed }\end{array}$ & $\begin{array}{l}56.9 \\
30.0 \\
13.1\end{array}$ & $\begin{array}{l}46.7 \\
35.9 \\
17.4\end{array}$ & $\begin{array}{l}51.7 \\
33.0 \\
15.3\end{array}$ & .177 \\
\hline Ever lived in the United States (\%) & 48.1 & 62.3 & 55.4 & .010 \\
\hline In touch with family (\%) & 84.9 & 80.7 & 82.8 & .318 \\
\hline Social support score (M, S.D.) & $12.4(3.5)$ & $12.1(3.6)$ & $12.3(3.6)$ & .413 \\
\hline \multicolumn{5}{|l|}{ Motive of admission (\%) } \\
\hline $\begin{array}{l}\text { Voluntary } \\
\text { At request of family/friends }\end{array}$ & $\begin{array}{l}66.0 \\
34.0\end{array}$ & $\begin{array}{l}56.0 \\
44.1\end{array}$ & $\begin{array}{l}60.9 \\
39.1\end{array}$ & .062 \\
\hline $\mathrm{MMSE}^{2}(\mathrm{M}, \mathrm{S} . \mathrm{D})$. & $26.7(2.2)$ & $26.9(2.2)$ & $26.8(2.2)$ & .470 \\
\hline \multicolumn{5}{|l|}{ Previous month use (\%) } \\
\hline $\begin{array}{l}\text { Alcohol } \\
\text { Cocaine/crack } \\
\text { Metamphetamine/amphetamine } \\
\text { Heroine/opioids } \\
\geq 2 \text { drugs }\end{array}$ & $\begin{array}{r}69.6 \\
19.1 \\
81.7 \\
8.3 \\
59.5\end{array}$ & $\begin{array}{l}63.2 \\
17.2 \\
81.6 \\
27.6 \\
66.9\end{array}$ & $\begin{array}{l}66.4 \\
18.1 \\
81.6 \\
18.1 \\
63.2\end{array}$ & $\begin{array}{r}.223 \\
.654 \\
.991 \\
<.001 \\
.171\end{array}$ \\
\hline \multicolumn{5}{|l|}{ Previous treatment (median, $\mathrm{IQR}^{2}$ ) } \\
\hline $\begin{array}{l}\text { Residential } \\
\text { Outpatient }\end{array}$ & $\begin{array}{l}1(0-3) \\
0(0-1)\end{array}$ & $\begin{array}{l}2(0-5) \\
0(0-1)\end{array}$ & $\begin{array}{l}1(0-4) \\
0(0-1)\end{array}$ & $\begin{array}{l}.109 \\
.075\end{array}$ \\
\hline \multicolumn{5}{|l|}{ DUREL ${ }^{2}$} \\
\hline $\begin{array}{l}\text { Organized religious activities } \\
\text { Non-organized religious activities } \\
\text { Intrinsic religiosity }\end{array}$ & $\begin{array}{l}2.8(1.8) \\
2.6(1.8) \\
4.0(1.2)\end{array}$ & $\begin{array}{l}2.5(1.5) \\
2.9(1.8) \\
3.7(1.4)\end{array}$ & $\begin{array}{l}2.7(1.7) \\
2.8(1.8) \\
3.8(1.3)\end{array}$ & $\begin{array}{l}.173 \\
.276 \\
.042\end{array}$ \\
\hline \multicolumn{5}{|l|}{ Religious affiliation (\%) } \\
\hline $\begin{array}{l}\text { None } \\
\text { Catholic } \\
\text { Non-Catholic Christian } \\
\text { Other }\end{array}$ & $\begin{array}{r}31.8 \\
19.5 \\
42.9 \\
5.8\end{array}$ & $\begin{array}{r}39.5 \\
29.6 \\
24.1 \\
6.8\end{array}$ & $\begin{array}{r}35.8 \\
24.7 \\
33.2 \\
6.3\end{array}$ & .004 \\
\hline
\end{tabular}

Note: ${ }^{1} p$-value for difference between centers. $\chi^{2}$ test for difference of percentages, $t$ test for difference of means, rank sum test for variables with non-normal distribution; ${ }^{2} \mathrm{MMSE}=$ Mini-mental State Examination; IQR $=$ inter-quartile range; DUREL = Duke University Religion Index.

Similar to the findings of another study (Arndt et al., 2013), age had a direct association with retention. We cannot explain this finding, but from field observations we believe that it might be the case that older drug users are readier for a "time out" of drug use due to the physical consequences of it. However, the association could also be due to confounding by unmeasured variables.

On the other hand, social support has been shown to increase drug treatment retention (Lang \& Belenko, 2000; Lewandowski \& Hill, 2009). While we did not find an association with contact with family or perceived social support, the association between admission at family/friends request and retention might in part be explained by closer social relationships. Field observation in $\mathrm{C} 2$ showed that those admitted at family request were placed in a more closely monitored sleeping area within the center. However, an analysis adjusting for sleeping area still showed a significant association between admission at request of family/friends and retention in $\mathrm{C} 2$, so we might speculate that for this study the variable was a proxy, either of special living conditions within the center, or of other effects of family involvement in the client's treatment.

As opposed to other studies (Meier et al., 2006; Tate et al., 2008), none of the psychological variables explored had an association with retention in the multivariate model. On the other hand, heroin/opioid use was associated with 


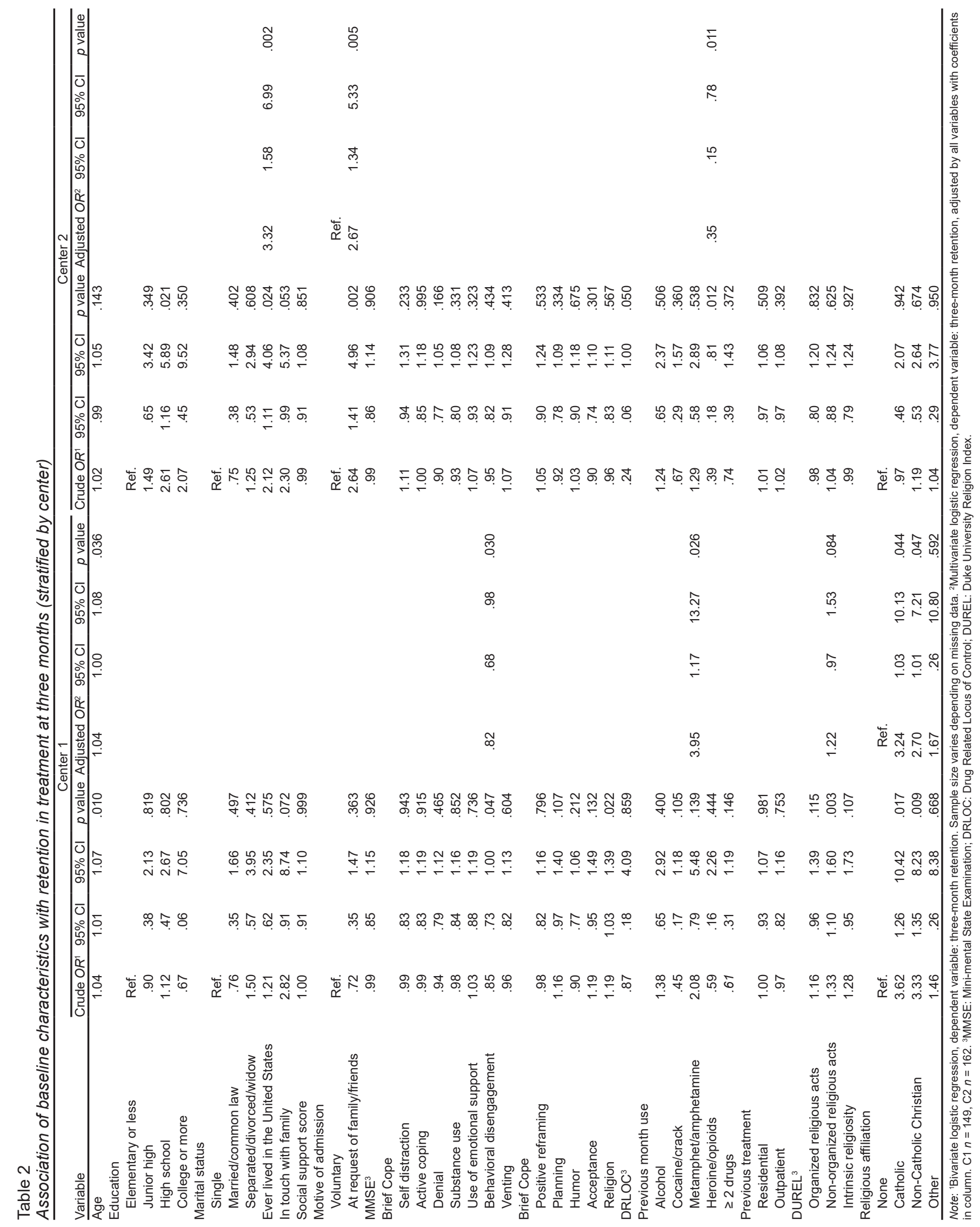


Table 3

Association of baseline characteristics with retention in treatment at three months (both centers)

\begin{tabular}{lrrrr}
\hline Variable & $\mathrm{OR}^{1}$ & $95 \% \mathrm{Cl}$ & $95 \% \mathrm{Cl}$ & $p$-value \\
\hline Center (reference C1) & 2.74 & .95 & 7.85 & .061 \\
Age & 1.04 & 1.01 & 1.06 & .002 \\
Motive of admission & & & & \\
$\quad$ Voluntary & Ref. & & & \\
$\quad$ At request of family/friends & .85 & .38 & 1.87 & .680 \\
C2* Admitted at request & 3.41 & 1.19 & 9.72 & .022 \\
of family/friends & & & & \\
Used heroine/opioids & .50 & .25 & 1.00 & .049 \\
in past month & & & & \\
Religious affiliation & & & & \\
$\quad$ None & Ref. & & & \\
Catholic & 3.77 & 1.27 & 11.20 & .017 \\
$\quad$ Non-Catholic Christian & 3.03 & 1.19 & 7.74 & .020 \\
$\quad$ Other & 2.11 & .35 & 12.71 & .415 \\
C2*Catholic & .19 & .05 & .74 & .017 \\
C2*Non-Catholic Christian & .40 & .11 & 1.40 & .150 \\
C2*Other & .61 & .06 & 5.92 & .670 \\
\hline
\end{tabular}

Note: ${ }^{1}$ Multivariate logistic regression, dependent variable: three-month retention, adjusted by all variables in Table. $N=313$.

lower odds of retention, as has been reported before (Arndt et al., 2013). This might be due to the strong addictive properties of this group of substances, combined with the lack of a specific therapy for the management of withdrawal in the participant centers. In future studies, it will be interesting to continue exploring if and which psychological traits are associated with retention in this population, and how to address the needs of clients with different drug use patterns.

Regarding the religious aspects, it is interesting to notice that $\mathrm{C} 1$, the $\mathrm{EP}$ center, received more clients who were affiliated with a religion and spiritually oriented. In addition, those who started treatment at $\mathrm{C} 1$ were more likely to stay if they were either Non-Catholic Christian or Catholic, as compared to those without religious affiliation. The association was more marked amongst Catholics. Although any interpretation is speculative, we think this indicates that having a religious or spiritual disposition facilitated retention in $\mathrm{C} 1$, where religious aspects were a more salient part of the treatment. While it could be hypothesized that the concordance between the specific religious affiliation of center and client would be important in this regard, according to our data it was not concordance in affiliation (i.e., being a Non-Catholic Christian in a Non-Catholic Christian center), but the agreement between the general religious orientation of client and center, that was associated with increased retention. At $\mathrm{C} 2$, where religion has a less salient place in the treatment model, most clients had no religious affiliation, and affiliation made no difference in terms of retention. Conversely, for those with no religious affiliation retention was significantly higher at $\mathrm{C} 2$. These results suggest that the outcome of treatment in faith-based centers might depend on the initial religious/spiritual condition of the client. However, the interrelations between religion and spirituality, and mental health treatment, are very complex (Vanderpot, 2014), and more in-depth exploration is guaranteed.

An important limitation of our data is the high proportion of those admitted at the centers that were not enrolled in the study. Given the lack of information about those not enrolled, it is difficult to assess the representativeness of our sample. The participants' distribution by age and drug of use was similar to what is reported for Baja California by the national addiction surveillance system (Secretaría de Salud, 2015), but we cannot assess if they were comparable in terms of other characteristics. Thus, a recommendation for future studies in this type of centers is that the research team collects its own statistics of admissions to assess selection bias. Another limitation of our study was that, having collected data in only two centers, the results cannot be generalized to the population of non-governmental centers in either Tijuana or Mexico.

To conclude, the faith-based centers in this study had a low retention rate that was associated with personal religious affiliation in the EP center. This suggests that a match between a person's religious convictions and those of the center could be important for retention. In the absence of sufficient public services for substance use disorders in Mexico's health system (Garcia, 2015; Lozano-Verduzco et al., 2015; Marín-Navarrete et al., 2013), the initiatives of civil society and religious groups will continue being the main source of attention for the most vulnerable population. In this context, more research is needed to clarify the utility of faith-based centers for religious and non-religious drug users, and to suggest ways of improvement.

\section{Funding}

This study was funded by Consejo Nacional de Ciencia y Tecnología.

\section{Conflicts of interests}

The authors declare they have no conflicts of interests.

\section{Acknowledgments}

We thank the staff and clients of the two participating centers for their support.

\section{REFERENCES}

Aharonovich, E., Hasin, D. S., Brooks, A. C., Liu, X., Bisaga, A., \& Nunes, E. V. (2006). Cognitive deficits predict low treatment retention in cocaine dependent patients. Drug and Alcohol Dependence, 81(3), 313-322. doi: 10.1016/j.drugalcdep.2005.08.003

American Psychiatric Association \& Work Group on Substance Use Disorders. (2010). Practice Guideline for the Treatment of Patients With Substance Use Disorders. American Psychiatric Association. 
Arndt, S., Acion, L., \& White, K. (2013). How the states stack up: disparities in substance abuse outpatient treatment completion rates for minorities. Drug and Alcohol Dependence, 132(3), 547-554. doi: 10.1016/j.drugalcdep.2013.03.015

Berenzon, S., Saavedra, N., Medina-Mora, M. E., Aparicio, V., \& Galván, J. (2013). Evaluación del sistema de salud mental en México: ¿hacia dónde encaminar la atención?. Revista Panamericana de Salud Pública, 33(4), 252-258.

Borson, S., Scanlan, J. M., Watanabe, J., Tu, S. P., \& Lessig, M. (2005). Simplifying detection of cognitive impairment: comparison of the Mini-Cog and Mini-Mental State Examination in a multiethnic sample. Journal of the American Geriatrics Society, 53(5), 871-874. doi: 10.1111/j.1532-5415.2005.53269.x

Carver, C. S. (1997). You want to measure coping but your protocol's too long: consider the brief COPE. International Journal of Behavioral Medicine, 4(1), 92100. Retrieved from: http://www.psy.miami.edu/faculty/ccarver/sclspan.html

Evans, E., Li, L., \& Hser, Y. I. (2009). Client and program factors associated with dropout from court mandated drug treatment. Evaluation and Program Planning, 32(3), 204-212. doi: 10.1016/j.evalprogplan.2008.12.003

Folstein, M. F., Folstein, S. E., \& McHugh, P. R. (1975). "Mini-mental state". A practical method for grading the cognitive state of patients for the clinician. Journal of Psychiatric Research, 12(3), 189-198. Retrieved from: http://www.dgplades. salud.gob.mx/Contenidos/Documentos/MMSE.pdf

Galaviz, G. \& Odgers, O. (2014). Estado laico y alternativas terapéuticas religiosas. El caso de México en el tratamiento de adicciones. Debates do NER, 2(26), 253-276.

Garcia, A. (2015). Serenity: Violence, Inequality, and Recovery on the Edge of Mexico City. Medical anthropology quarterly, 29(4), 455-472. doi: 10.1111/ maq. 12208

Garnick, D. W., Lee, M. T., Horgan, C. M., Acevedo, A., \& Washington Circle Public Sector, W. (2009). Adapting Washington Circle performance measures for public sector substance abuse treatment systems. Journal of Substance Abuse Treatment, 36(3), 265-277. doi: 10.1016/j.jsat.2008.06.008

Hall, E. A. (2001). Feelings about drug use: Drug-related locus of control. Los Angeles, CA: UCLA Integrated Substance Abuse Programs.

Hernandez, O. L. O., \& Ortiz, O. O. (2015). Renacer en Cristo. Cuerpo y subjetivación en la experiencia de rehabilitación de adicciones en los centros evangélico pentecostales. Ciencias Sociales y Religión/Ciências Sociais e Religião, 17(22), 90-119.

Instituto Nacional de Psiquatría Ramón de la Fuente Muñiz, Instituto Nacional de Salud Pública, Comisión Nacional Contra las Adicciones, \& Secretaría de Salud. (2017). Encuesta Nacional de Consumo de Drogas, Alcohol y Tabaco 20162017: Reporte de Drogas. Ciudad de México: INPRFM.

Koenig, H. C., \& Büssing, A. (2010). The Duke University Religion Index (DUREL): A Five-Item Measure for Use in Epidemological Studies. Religions, 1(1), 78-85.

Lang, M. A., \& Belenko, S. (2000). Predicting retention in a residential drug treatment alternative to prison program. Journal of Substance Abuse Treatment, 19(2), 145-160.

Lewandowski, C. A. \& Hill, T. J. (2009). The impact of emotional and material social support on women's drug treatment completion. Health \& Social Work, 34(3), 213-221.

Lozano-Verduzco, I., Marín-Navarrete, R., Romero-Mendoza, M., \& Tena-Suck, A. (2015). Experiences of Power and Violence in Mexican Men Attending Mutual-Aid Residential Centers for Addiction Treatment. American Journal of Men's Health, 10(3), 237-249. doi: 10.1177/1557988314565812
Marín-Navarrete, R., Eliosa-Hernández, A., Lozano-Verduzco, I., Fernández-De la Fuente, C., Turnbull, B., \& Tena-Suck, A. (2013). Estudio sobre la experiencia de hombres atendidos en centros residenciales de ayuda mutua para la atención de las adicciones. Salud Mental, 36(5), 393-402.

McKellar, J., Kelly, J., Harris, A., \& Moos, R. (2006). Pretreatment and during treatment risk factors for dropout among patients with substance use disorders. $\mathrm{Ad}$ dictive Behaviors, 31(3), 450-460. doi: 10.1016/j.addbeh.2005.05.024

Meier, P. S. \& Best, D. (2006). Programme factors that influence completion of residential treatment. Drug and Alcohol Review, 25(4), 349-355. doi: 10.1080/09595230600741230

Meier, P. S., Donmall, M. C., McElduff, P., Barrowclough, C., \& Heller, R. F. (2006). The role of the early therapeutic alliance in predicting drug treatment dropout. Drug and Alcohol Dependence, 83(1), 57-64. doi: 10.1016/j.drugalcdep.2005.10.010

Mokri, H., Ávila-Funes, J. A., Meillon, C., Gutierrez R. L. M., \& Amieva, H. (2013). Normative data for the Mini-Mental State Examination, the Free and Cued Selective Reminding Test and the Isaacs Set Test for an older adult Mexican population: the Coyoacan cohort study. The Clinical Neuropsychologist, 27(6), 1004-1018. doi: 10.1080/13854046.2013.809793

Mulder, R. T., Frampton, C. M., Peka, H., Hampton, G., \& Marsters, T. (2009). Predictors of 3-month retention in a drug treatment therapeutic community. Drug and Alcohol Review, 28(4), 366-371. doi: 10.1111/j.1465-3362.2009.00050.x

Odgers, O., Galaviz, G., \& Hernandez, A. (2009). Tendencias del cambio religioso en la región norte de México. In: A. Hernandez \& C. Rivera (Eds.), Regiones y religiones en México, estudios de la transformación sociorreligiosa. Tijuana: El Colegio de la Frontera Norte.

Parhami, I., Davtian, M., Collard, M., Lopez, J., \& Fong, T. W. (2014). A preliminary 6-month prospective study examining self-reported religious preference, religiosity/spirituality, and retention at a Jewish residential treatment center for substance-related disorders. The Journal of Behavioral Health Services \& Research, 41(3), 390-401. doi: 10.1007/s11414-012-9279-x

Secretaría de Salud. (2015). Sistema de Vigilancia Epidemiológica para las Adicciones. Informe 2014. Ciudad de México: Secretaría de Salud.

StataCorp, L. P. (2013). Stata Statistical Software: Release 13. College Station, TX: StataCorp LP.

Stoll, D. (1990). Is Latin America turning protestant? The politics of evangelical growth. Berkeley: University of California Press.

Sung, H. E. \& Chu, D. C. (2013). The varieties of religious experience and the retention of clients in Taiwanese faith-based residential drug user treatment. Substance Use \& Misuse, 48(12), 1219-1232. doi: 10.3109/10826084.2013.805597

Tate, S. R., Wu, J., McQuaid, J. R., Cummins, K., Shriver, C., Krenek, M., \& Brown, S. A. (2008). Comorbidity of substance dependence and depression: role of life stress and self-efficacy in sustaining abstinence. Psychology of Addictive Behaviors, 22(1), 47-57. doi: 10.1037/0893-164X.22.1.47

Vanderpot, L. E. (2014). Case study explorations of the interrelationship between spirituality and psychiatric medication use. Spirituality in Clinical Practice, 1(4), 300-306.

Zhang, Z., Friedmann, P. D., \& Gerstein, D. R. (2003). Does retention matter? Treatment duration and improvement in drug use. Addiction, 98(5), 673-684. 